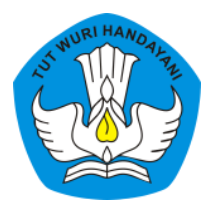

Page: 587-606

\title{
PENGGUNAAN MEDIA POHON AKAR PANGKAT TIGA (PAKAR PATI) UNTUK MENINGKATKAN KEMAMPUAN BERPIKIR KRITIS PADA PEMBELAJARAN MATEMATIKA
}

\author{
Subiarto \\ Sekolah Dasar Negeri 1 Kendaga, Banjarnegara, Jawa Tengah, Indonesia \\ Contributor Email: subiarto55@ymail.com
}

Received: Feb 08, 2021

Accepted: Mei 06, 2021

Published: Jul 30, 2021

Article Url: $\underline{\text { https://ojsdikdas.kemdikbud.go.id/index.php/didaktika/article/view/252 }}$

\begin{abstract}
The research objective was to improve critical thinking skills and mathematics learning outcomes through the use of Pakar Pati (Pohon Akar Pangkat Tiga) media of fifth grade students of SD Negeri 1 Kendaga. The research subjects in the study were 25 fifth grade students at SD Negeri 1 Kendaga. The method used in this research was classroom action research, by performing two actions in two cycles. Each cycle had four stages of activity, namely planning, implementation, observation and reflection. The results of this study indicated that the use of cube root tree media (Pakar Pati) can improve critical thinking skills in learning mathematics for fifth grade students of SD Negeri 1 Kendaga. Students' ability to formulate problems, collect data, analyze, ask and answer questions, make observations and provide conclusions increases. Learning outcomes increased in the ability to solve problems and understand the cube root material.
\end{abstract}

Keywords: Critical Thinking; Learning Outcome; Mathematics. 


\begin{abstract}
Abstrak
Tujuan penelitian ini adalah untuk meningkatkan kemampuan berpikir kritis dan hasil belajar matematika melalui penggunaan media Pakar Pati (Pohon Akar Pangkat Tiga) bagi siswa kelas V SD Negeri 1 Kendaga. Subjek penelitian ini adalah 25 siswa kelas $V$ di SD Negeri 1 Kendaga. Metode yang digunakan dalam penelitian ini adalah metode penelitian tindakan kelas, dengan melakukan dua tindakan dalam dua siklus. Tiap siklus ada empat tahap kegiatan yaitu perencanaan, pelaksanaan, observasi, dan refleksi. Hasil penelitian ini menunjukkan bahwa penggunaan media pohon akar pangkat tiga (Pakar Pati) dapat meningkatkan kemampuan berpikir kritis belajar matematika bagi siswa kelas V SD Negeri 1 Kendaga. Kemampuan siswa dalam merumuskan masalah, mengumpulkan data, menganalisis, menanyakan dan menjawab pertanyaan, serta melakukan observasi dan memberikan kesimpulan meningkat. Hasil belajar meningkat dalam kemampuan memecahkan masalah dan memahami materi akar pangkat tiga.
\end{abstract}

Kata Kunci: Berpikir Kritis; Hasil Belajar; Matematika.

\title{
A. Pendahuluan
}

Pembelajaran matematika sekolah dasar bertujuan melatih cara berfikir secara sistematis, kretaif, kritis, logis, dan konsisten. Pembelajaran matematika daharapkan dapat mengembangkan pola pikir kritis, yang logis, sistematis, dengan penuh kehati-hatian, dan cermat. Dalam pembelajaran sering terjadi pengembangan model pembelajaran matematika tidak sejalan dengan perkembangan berfikir pada usia anak SD. Guru menganggap jelas dan logis, tetapi bisa terjadi hal yang membingungkan bagi siswa.

Matematika adalah pengetahuan dan ilmu logika dan problemproblem numerik. Muhysetyo (2007) mengungkapkan bahwa pembelajaran matematika merupakan proses kegiatan belajar yang dilakukan siswa melalui berbagai kegiatan yang telah direncanakan agar diperoleh kompetensi tentang materi matematika bagi siswa.

Perkembangan anak itu berbeda dengan orang dewasa, hal ini tampak dari cara berfikir dan cara bertindak. Anak usia SD pada umumnya berada pada tahap berpikir operasional konkret yaitu mempunyai kemampuan berpikir logis, terhadap benda konkret. Kenyataan di lapangan para guru dalam pembelajaran hanya dalam bentuk verbal, sehingga sulit diterima anak. 
Berpikir adalah suatu keaktifan pribadi manusia yang mengakibatkan penemuan yang terarah pada suatu tujuan. Ciri utama dari berpikir adalah adanya proses abstraksi. Abstraksi berarti anggapan lepasnya relasi atau kualitas dari situadi-situasi, benda-benda, dan peristiwa-peristiwa yang mula-mula ditemukan sebagai kenyataan (Puwanto, 2008). Menurut Iskandar (2009), "Berpikir merupakan proses pengetahuan hubungan antara stimulus dan respon dari kegiatan kognitif tingkat tinggi (higher level cognitive)". Siswa perlu untuk mengembangkan berpikir kritis dalam belajar.

Banyak faktor yang memengaruhi hasil belajar siswa baik itu faktor dari luar diri siswa seperti situasi belajar, lingkungan, latar belakang sosial orangtua, sarana prasarana, dan sebagainya. Faktor dari dalam diri siswa meliputi kepercayaan diri, motivasi, minat, komunikasi lisan, dan keberanian. Salah satu faktor utama dalam penelitian ini adalah kemampuan berpikir kritis.

Berpikir kritis merupakan proses mental untuk mengevaluasi informasi, yang informasi itu diperoleh dari pengalaman, hasil pengamatan, komunikasi atau akal sehat (Deswani, 2009). Harsanto (2005) menyatakan berpikir kritis merupakan salah satu bentuk agar menjadi orang kritis diperlukan pikiran harus terbuka, berdasarkan fakta dan jelas. Seorang pemikir diharapkan dapat memberi alasan atas diambilnya keputusan dari berbagai perbedaan yang ada dengan memberikan alasan yang logis dan jelas.

Pembelajaran matematika di SD Negeri 1 Kendaga berdasarkan hasil pengamatan pada kelas $\mathrm{V}$ semester II pada materi akar pangkat tiga merupakan materi yang dianggap sulit. Dalam pembelajaran matematika di jumpai permasalahan yang menghambat kelancaran pembelajaran matematika dalam meningkatkan kemampuan berpikir kritis dan hasil belajar. Permasalahan rendahnya kemampuan berpikir kritis pada siswa saat pembelajaran matematika berlangsung ditunjukkan dengan siswa tergantung kepada guru, tidak ada keberanian untuk menyatakan idenya. Siswa kurang aktif bertanya, ditambah kurangnya kreativitas guru dalam pembelajaran yang beragam misalnya diskusi, tanya jawab, demonstrasi, 
inquiri, eksperimen, dan teknik-teknik pembelajaran tertentu sesuai dengan tujuan pembelajaran dan penggunaan media pembelajaran.

Menurut Nasution (2005) media merupakan alat bantu dalam mengajar supaya pembelajran menjadi efektif. Media merupakan alat untuk menerangkan atau mewujudkan konsep. Media pendidikan dapat digunakan oleh guru untuk membantu memperjelas materi pelajran dalam proses pembelajararan agar pembejaran, proses komunikasi dapat berhasil dan berjalan secara efektif dan baik. Hal senada disampaikan Hamzah (2001) bahwa media merupakan alat-alat atau benda yang dapat dilihat maupun didengar agar membantu cara berkomunikasi lebih efektif.

Media akan mudah digunakan apabila dipersiapkan, dirancang, dan dibuat sendiri. Penggunakan media yang tepat dapat menumbuhkan respon positif bagi siswa, sehingga melatih daya pikir dan perkembangan siswa. Namun, pembuatan media membutuhkan waktu dan tenaga yang tidak sedikit, untuk memilih dan mempersiapkan bahan, serta proses pembuatannya.

Berdasarkan hasil pengamatan yang dilakukan oleh penulis selama pembelajaran matematika berlangsung, kemampuan berpikir kritis siswa dapat dikatakan belum memuaskan atau belum sesuai harapan. Kemampuan siswa dalam merumuskan masalah, mengumpulkan data, menganalisis, melakukan observasi dan memberikan kesimpulan masih rendah. Hasil pengamatan pada prasiklus menunjukkan bahwa dari sejumlah 25 siswa, hanya 8 siswa atau sebesar 32\% yang terlihat mempunyai kemampuan berpikir kritis yang tinggi, sebanyak 7 siswa atau sebesar 28\% kategori kemampuan berpikir kritis sedang, dan selebihnya 10 siswa atau sebesar 40\% kategori kemampuan berpikir kritis rendah.

Rendahnya kemampuan berpikir kritis ternyata memengaruhi hasil belajar matematika. Hal ini dapat dilihat dari data ulangan harian yang dilakukan oleh peneliti, menunjukkan nilai rata-rata sebesar 62,88 , siswa yang mendapatkan nilai di atas atau sama dengan KKM sebanyak 10 siswa atau hanya sebesar 40\% dengan KKM sebesar 70.

Hasil belajar sebagai pedoman dan tolak ukur yang dipakai untuk menentukan tingkat keberhasilan siswa dalam memahami dan mengetahui $590\}$ Ditjen GTK Pendidikan Dasar Kemendikbud R.I 
materi mata pelajaran. Hasil belajar dapat diwujudkan dengan nilai yang biasanya berupa huruf-huruf atau angka. Hasil belajar dapat berupa pengetahuan, sikap dan keterampilan, setelah siswa mengalami proses belajar.

Hasil belajar merupakan kompetensi yang diperoleh siswa setelah mengikuti pembelajaran sebagai hasil pengalaman belajar. Menurut Sudjana (2004) hasil belajar adalah sesuatu yang didapat atau diperoleh seseorang setelah melakukan kegiatan belajar. Hasil belajar tampak dari perubahan perilaku pada diri siswa, yang dapat diukur dan diamati dalam bentuk perubahan sikap, pengetahuan, dan keterampilan. Hamalik (2002) mengungkapkan bahwa perubahan perilaku dapat diartikan terjadinya pengembangan dan peningkatan yang lebih baik dibandingkan dengan sebelumnya. Menurut Arikunto (2012) hasil belajar adalah hasil yang diperoleh seseorang setelah mengikuti proses pembelajaran dan mengikuti evaluasi dari proses pembelajaran yang dilaksanakan.

Selain itu suasana pembelajaran berlangsung kurang santai dan terlalu serius, di dalam kelas kurang terdengar suara tepuk tangan atau sorak-sorai untuk memberikan semangat kepada temannya yang berhasil atau hendak mengerjakan soal ke depan kelas.

Pembelajaran yang sering dilakukan adalah menggunakan model pembelajaran ceramah dan latihan mengerjakan soal. Siswa tidak diajak untuk berpikir bagaimana mengkongkritkan soal sehingga akan lebih bermakna. Sehingga berdampak hasil belajar yang rendah. Penyebab lain rendahnya hasil belajar adalah kurangnya penggunaan media pembelajaran saat proses pembelajaran berlangsung.

Pembelajaran yang berkaitan dengan akar pangkat tiga sebenarnya dapat dilaksanakan dalam pembelajaran yang konkret dan menyenangkan Salah satu alat bantu untuk mengkonkretkan materi akar pangkat tiga yaitu media pohon akar pangkat tiga (media pakar pati).

Salah satu metode belajar yang dapat untuk mengaktifkan dan agar peseta didik dapat mengembangkan kemampuan berpikir kritis adalah metode demonstrasi dan eksperimen. Menurut Rusmiati (2007) 
metode demonstrasi merupakan kegiatan mempertontonkan proses terjadinya suatu kejadian, urutan melakukan kegiatan dengan pemberian contoh benda nyata atau tiruan agar siswa lebih tahu dan paham. Metode eksperimen menurut Djamarah (2002) adalah cara mengajar, di mana siswa melakukan kegaitan percobaan agar mengalami sendiri sesuai materi yang dipelajari

Berdasarkan permasalahan di atas untuk mengatasi masalah maka akan dibuat strategi pembelajaran untuk meningkatkan kemampuan berpikir kritis siswa dan mengonkretkan materi akar pangkat tiga dengan menggunakan media pembelajaran Pohon Akar Pangkat Tiga (Pakar Pati). Media Pakar Pati adalah media yang dibuat dari karton/kayu, lingkaran, gambar pohon yang digunakan untuk mengajarkan materi akar pangkat tiga.

Rumusan masalah dalam penelitian ini adalah bagaimana penggunaan media Pakar Pati dapat meningkatkan kemampuan berpikir kritis dan hasil belajar matematika pada siswa kelas V SD Negeri 1 Kendaga semester II tahun pelajaran 2019/2020. Tujuan penelitian ini adalah untuk mendeskripsikan peningkatan kemampuan berpikir kritis dan hasil belajar matematika melalui penggunaan media pakar pati pada siswa kelas V SD Negeri 1 Kendaga semester II tahun pelajaran 2019/2020.

\section{B. Metode}

Penelitian ini dilakukan di SD Negeri 1 Kendaga Kecamatan Banjarmangu Kabupaten Banjarnegara. Penelitian ini dilakukan pada mata pelajaran matematika selama 2 siklus. Penelitian ini dilaksanakan selama 4 bulan pada bulan Januari sampai bulan April 2020.

Subjek penelitian adalah siswa SD negeri 1 Kendaga kelas $\mathrm{V}$ yang berjumlah 25, terdiri dari 12 siswa perempuan dan 13 siswa laki-laki dengan karakteristik siswa memiliki potensi dan kompetensi yang heterogen.

Teknik yang dipakai dalam mengumpulkan data menggunakan alat tes dan nontes. Tes yang digunakan untuk mengetahui prestasi belajar. Teknik nontes berupa observasi dengan lembar observasi dan catatan untuk menilai kemampuan berfikir kritis selama pembelajaran berlangsung. Analisis data yang dipakai dalam penelitian ini dipaparkan dalam bentuk 
analisis kualitatif melalui pemaparan data yang diperoleh secara deskriptif komparatif. Analisis kualitatif dilakukan dengan mendesripsikan kegiatan pembelajaran tiap-tiap siklus dalam penelitian dan disertai data-data kualitatif yang dilakukan secara sederhana.

Penelitian ini dilaksanakan dengan menggunakan metode penelitian tindakan kelas terdiri dari 2 siklus. Prosedur umum penelitian ini melalui tahapan planning, acting, observing dan reflecting. Langkah kegiatan meliputi 2 siklus dengan tahapan tiap siklus perencanaan, pelaksanaan, pengamatan dan refleksi.

Langkah pertama yakni menyusun rencana tindakan. Pada bagian ini, penulis melakukan perencanaan tindakan untuk meningkatkan kemampuan berpikir kritis dan hasil belajar melalui penggunaan media Pakar Pati dengan metode demonstrasi dan ekperimen. Adapun langkahnya adalah menetapkan setting dan waktu pelaksanaan penelitian dengan 2 siklus dan setiap siklus 3 pertemuan, menetapkan materi pembelajaran tentang akar pangkat tiga, membuat izin penelitian, rekomendasi dari kepala sekolah, dan membuat pernyataan kesediaan sebagai kolaborator, menyusun rancangan penelitian terdiri dari rancangan penelitian tindakan kelas dan jurnal kegiatan penelitian, menyusun rencana pelaksanaan pembelajaran sesuai dengan sintak pembelajaran melalui penggunaan Pakar Pati dengen metode demonstrasi dan ekperimen, dan membuat media Pakar Pati.

Langkah kedua yakni melaksanakan tindakan. Pelaksanaan pembelajaran yang diterapkan terdiri dari dua siklus dengan masing-masing siklus terdiri dari dua kali pertemuan. Tahap pelaksanaan pembelajaran meliputi hal sebagai berikut.

Pada kegiatan pendahuluan, guru mengawali pembelajaran dengan mengucapkan salam, dan mengajak siswa memulai pelajaran dengan berdoa. Guru memeriksa kondisi kelas dan mengecek kehadiran siswa. Guru menyampaikan materi, tujuan pembelajaran dan model pembelajaran yang digunakan. Guru menyampaikan apersepsi, mengecek kemampuan prasarat siswa dengan tanya jawab. Guru mempersiapkan alat peraga yang akan digunakan. 
Kegiatan inti yakni dengan mempersiapkan bahan/alat yang dibutuhkan. Guru menyampaikan informasi supaya siswa akatif dan terlibat langsung sewaktu pembelajaran. Guru menunjukkan alat peraga Pakar Pati dan memberikan penjelasan tentang petunjuk dan langkah-langkah kegiatan demonstrasi dan eksperimen yang akan dilakukan menggunakan Pakar Pati. Guru/siswa mendemonstrasikan cara penggunaan Pakar Pati Siswa dibagi kelompok secara heterogen dan memperhatikan gender. Siswa secara kelompok melakukan eksperimen sesuai tugas untuk menghitung akar pangkat tiga menggunakan Pakar Pati. Guru membimbing kelompok atau siswa yang mengalami kesulitan. Perwakilan kelompok mempresentasikan hasil percobaan/diskusi kelompoknya. Hasil pekerjaan kelompok di tukar dengan kelompok lain untuk di koreksi Pembahahasn hasil tugas secara klasikal. Guru memberikan penghargaan kepada kelompok terbaik. Siswa memajang hasil diskusi. Guru menekankan nilai-nilai pendidikan karakter.

Pada kegiatan penutup, guru memberi kesempatan kepada siswa untuk membuat membuat rangkuman dan refleksi dari pembelajajaran yang telah dilakukan pada hari ini. Siswa diberi tugas oleh guru agar mempelajari materi berikutnya. Guru memberikan motovasi dan memberi informasi kepada siswa tentang rencana kegiatan pembelajaran pada pertemuan mendatang. Guru menutup pelajaran dengan memberi salam.

Langkah ketiga yakni melaksanakan pengamatan. Pengamatan atau observasi untuk mengetahui prose pembelajaran dan tindakan yang diterapkan berorientasi ke masa yang akan datang, memberi dasar bagi kegiatan refleksi yang kritis. Kegiatan ini dilakukan oleh observer dengan dibekali lembar pengamatan. Observer adalah teman sejawat sebagai guru kolaborator bertugas mengamati proses pembelajaran dan mengumpulkan data mengenai segala sesuatu yang terjadi pada proses pembelajaran. Observasi ini menggunakan lembar observasi pembelajaran melalui penggunaan Pakar Pati dengan metode demonstrasi dan ekperimen observer duduk di kelas bagian belakang.

Langkah keempat yakni melaksanakan refleksi (reflecting). Berdasarkan hasil observasi dan tes tertulis, selanjutnya dilakukan analisis dan refleksi. 
Hasil refleksi ini bertujuan untuk mengetahui hal-hal yang perlu ditingkatkan, keefektivan dan kekurangan pembelajaran. Hal ini sebagai bahan pertimbangan perbaikan tindakan pada siklus berikutnya.

\section{Hasil dan Pembahasan}

Pada penelitian ini data yang digunakan berupa skor hasil pengamatan, kemudian diinterpretasikan dalam analisis kualitatif dengan katagori tinggi, sedang, dan rendah. Untuk tes prestasi hasil belajar meliputi penilaian kognitif berupa data skor kuantitatif. Hasil analisis tes diperoleh skor tertinggi, skor terendah, rerata dan ketuntasan belajar siswa. Setelah dlaksankan perbaikan pembelajaran siklus I, didapat data sebagai berikut.

Data kemampuan berpikir kritis. Data tentang kemampuan berpikir kritis diambil setelah melakukan pembelajaran pada akhir siklus I, Instrumen data berupa lembar Lembar pengamatan kemampuan berpikir kritis terdiri dari 6 aspek, yaitu: memperhatikan demonstrasi, mengemukakan pendapat, keterampilan menggunakan media/media, kemampuan berpikir kritis dalam diskusi, kerja sama kelompok dan aktif menulis. Dari data diperoleh kemampuan berpikir kritis skor 1-2 kategori rendah, kemampuan berpikir kritis skor 3-4 kategori sedang, kemampuan berpikir kritis skor 5-7 kategori tinggi.

Pada siklus I diperoleh hasil, terlihat jumlah siswa yang kemampuan berpikir kritis rendah 3 siswa atau 12\%, kemampuan berpikir kritis sedang 7 siswa atau 28\%, kemampuan berpikir kritis tinggi 15 siswa atau $60 \%$.

Setelah pelaksanaan tindakan siklus I diadakan evaluasi dengan tes untuk mengukur kompetensi pengetahuan siswa. Hasil tes didapat data bahwa hasil tes hasil belajar siklus I menunjukkan siswa yang mendapatkan nilai lebih besar atau sama dengan kriteria ketuntasan minimal (KKM) yang ditetapkan yaitu 65 ada 17 siswa dengan ketuntasan belajar 68\%. Nilai tertinggi 94, nilai terendah 58 dengan rentang nilai 0 - 100 dengan nilai rata-rata 74,08 . Masih ada 8 siswa (32\%) yang memperoleh nilai di bawah KKM.

Pada akhir siklus I tampak bahwa kemampuan berpikir kritis tinggi baru mencapai 15 siswa atau 60\% padahal indikator keberhasilan penelitian 
yang ditetapkan kemampuan berpikir kritis yang tinggi adalah 75\%. Karena lebih rendah dari indicator maka penelitian siklus I belum berhasil. Hasil tes hasil belajar baru mencapai rerata 74,08 dengan indikator keberhasilan nilai rata-rata 75 sehingga belum berhasil.

Berdasarkan hasil observasi terhadap guru dan siswa serta tes evaluasi pelaksanaan siklus I, untuk mengetahui ketercapaian pelaksanaan pembelajaran melalui penggunaaan media pakar pati dengan metode demonstrasi dan eksperimen, guru kolaborator dan guru peneliti melakukan diskusi refleksi.

Dari hasil analisis dan diskusi bersama kolaborator diperoleh data sebagai berikut. Keberhasilan pelaksanaan pembelajaran menggunakan media Pakar Pati dengan metode demonstrasi dan ekperimen. Pada siklus I kemampuan berpikir kritis belajar sudah mulai tampak, selain itu tampak karakter disiplin, tanggung jawab, kerja sama dan jujur. Penggunaan media Pakar Pati sangat membantu siswa dalam memahami materi penjumlahan bilangan akar pangkat tiga. Siswa lebih bersemangat dan antusias dalam mengikuti pembelajaran melalui penggunaan Pakar Pati dengan metode demonstrasi dan ekperimen. Kemampuan berpikir kritis belajar siswa dengan kategori tinggi berjumlah 15 siswa atau 60\%. Hasil belajar pada siklus I menunjukkan terjadi peningkatan jika dibandingkan dengan hasil prasiklus yaitu dari 10 siswa atau $40 \%$ meningkat menjadi 17 siswa atau $68 \%$ yang memperoleh nilai sama atau di atas KKM.

Selain keberhasilan dalam pembelajaran juga ditemukan kekurangannya yaitu (1) guru kurang memotivasi siswa dalam belajar dan kurang merata dalam membimbing kelompok sehingga tidak semua siswa terlibat dalam kegiatan kelompok; (2) Terdapat beberapa siswa yang kurang aktif dan kurang antusias mengikuti pembelajaran hanya mengandalkan teman kelompok yang dianggap pintar; dan (3) Belum tercapainya indikator kemampuan berpikir kritis dan hasil belajar siswa.

Berdasarkan diskusi refleksi maka penelitian dilanjutkan siklus II dengan memotivasi pembimbingan yang merata tiap kelompok serta 
menambah kegiatan memperkecil kelompok. Hal ini sesuai pendapat Dimyati (2002) menyatakan bahwa pembelajaran menjadi efektif jika dilakukan secara kelompok kecil. Selain itu, memberi kesempatan siswa untuk diskusi dan mengunakan media pembelajaran. Media adalah suatu benda atau alat yang dapat dilihat oleh mata dan didengar dengan tujuan mempermudah dan membantu guru supaya proses pembelajaran berjalan lebih efisien dan efektif (Sudjana, 2004).

Pada siklus II, hasil penelitian untuk mendesripsikan kemampuan berpikir kritis siswa dalam proses pembelajaran mata pelajaran matematika, mengetahui seberapa besar hasil belajar siswa mata pelajaran matematika. Data yang dipakai dalam analisis penelitian ini berupa skor hasil pengamatan dan diinterpretasikan dalam analisis kualitatif dengan katagori tinggi, sedang, dan rendah. Untuk tes prestasi hasil belajar meliputi penilaian kognitif berupa data skor kuantitatif. Hasil analisis tes diperoleh skor tertinggi, skor terendah, rerata, dan ketuntasan belajar siswa.

Data tentang kemampuan berpikir kritis, data diambil setelah melakukan pembelajaran pada akhir siklus II. Dari hasil pengamatan kemampuan berpikir kritis siklus II tampak bahwa kemampuan berpikir kritis siswa meningkat. Hal ini ditunjukkan dari tidak ada siswa yang memiliki kategori kemampuan berpikir kritis rendah sebanyak 0 siswa atau $0 \%$, siswa yang memiliki kategori kemampuan berpikir kritis sedang sebanyak 2 siswa atau 8\%, dan siswa yang memiliki kategori kemampuan berpikir kritis tinggi sebanyak 23 siswa atau $92 \%$.

Setelah pelaksanaan tindakan siklus II diadakan evaluasi dengan tes untuk mengukur kompetensi pengetahuan siswa. Tes hasil belajar siklus II menunjukkan siswa yang mendapatkan nilai lebih besar atau sama dengan kriteria ketuntasan minimal (KKM) yang ditetapkan yaitu 65. Terdapat 22 siswa dengan ketuntasan belajar 88\%. Nilai tertinggi 100, nilai terendah 64 dengan rentang nilai 0 - 100 dengan nilai rata-rata 82,16

Diskusi refleksi dilakukan di SD Negeri 1 Kendaga dengan hasil analisis dan diskusi secara kolaboratif. Hasil observasi terhadap guru pada 
siklus II menunjukkan bahwa proses pembelajaran telah berlangsung sesuai dengan tujuan dan memperoleh nilai 90 atau sangat baik. Dari hasil pengamatan terhadap kemampuan berpikir kritis belajar siswa pada siklus II diperoleh kesimpulan kemampuan berpikir kritis belajar tinggi meningkat dari 15 siswa atau 60\% menjadi berjumlah 23 siswa atau $92 \%$. Hasil tes akhir kompetensi pengetahuan siklus II menunjukkan bahwa terjadi peningkatan jika dibandingkan dengan hasil tes akhir siklus I yaitu dari 17 siswa atau 68\% yang memperoleh nilai sama tau di atas KKM meningkat menjadi 22 siswa atau $88 \%$. Nilai rata-rata siklus II jika dibandingkan dengan siklus I yaitu dari rerata 74,08 meningkat menjadi 82,16.

Pada pengamatan prasiklus, kemampuan berpikir kritis tinggi hanya 8 siswa atau 32\% dari 25 siswa, kemampuan berpikir kritis sedang 7 siswa atau $28 \%$, dan kemampuan berpikir kritis rendah 10 siswa atau $40 \%$. Jadi kemampuan berpikir kritis yang tinggi pada prasiklus adalah 8 siswa atau $32 \%$. Setelah dilakukan pembelajaran dengan menggunakan media Pakar Pati dengan metode demonstrasi dan ekperimen kemampuan berpikir kritis mengalami peningkatan. Kemampuan berpikir kritis tinggi 15 siswa atau $60 \%$ dari 25 siswa, kemampuan berpikir kritis sedang 7 siswa atau $28 \%$, dan kemampuan berpikir kritis rendah 3 siswa atau $12 \%$. Jadi kemampuan berpikir kritis yang tinggi di siklus I ada 15 siswa atau $60 \%$.

Penggunaan media pakar pati membuat siswa lebih aktif dalam pembelajaran. Siswa melakukan demontrasi untuk memeragakan cara menghitung materi akar pangkat tiga. Siswa memeragakan cara menghitung, dan urutan melakukan kegiatan, untuk menemukan hasil dari akar pangkat tiga yang dicari. Siswa antusias dapal menggunakan media pakar pati.

Situasi pembelajaran matematika menggunakan media Pakar Pati dengan metode demonstrasi dan ekperimen, siswa memperhatikan demonstrasi dan aktif menggunakan media situasi kelas menjadi lebih aktif. Namun, kemampuan berpikir kritis tinggi belum mencapai indikator keberhasilan. Pada siklus II penerapan metode pembelajaran dengan perubahan memberikan motivasi dan memberikan pembimbingan yang lebih merata serta memperkecil 
kelompok mampu meningkatkan kemam-puan berpikir kritis secara optimal. Berdasarkan hasil pengamatan pada siklus II didapat data bahwa siswa yang mempunyai kemampuan berpikir kritis tinggi sebanyak 23 siswa atau 92\% dari 25 siswa, kemampuan berpikir kritis sedang sebanyak 2 siswa atau $8 \%$, dan kemampuan berpikir kritis rendah 0 siswa atau $0 \%$. Jadi kemampuan berpikir kritis di siklus II ada 23 siswa atau 92\%.

Perbandingan hasil penelitian pra siklus, siklus I dan siklus II setelah dilakukan pengamatan pada waktu proses pembelajaran didapat data sebagai berikut.

Tabel 1. Perbandingan Kemampuan berpikir kritis Prasiklus, Siklus I, dan Siklus II

\begin{tabular}{clccc}
\hline No & Kemampuan Berpikir Kritis & Prasiklus & Siklus I & Siklus II \\
1 & Tinggi & 8 & 15 & 23 \\
2 & Sedang & 7 & 7 & 2 \\
3 & Rendah & 10 & 3 & 0 \\
\hline
\end{tabular}

Hasil belajar mata pelajaran matematika yang diukur melalui tes prastasi menunjukkan hasil pada pra siklus rerata 62,88 dan ketuntasan 10 siswa atau $40 \%$. Setelah dilakukan pembelajaran dengan menggunakan media Pakar Pati ada peningkatan. Pada siklus I rerata 74,08 dan ketuntasan 17 siswa atau 68\%. Dari hasil refleksi hasil tersebut masih belum mencapai indikator keberhasilan. Dengan memperbaiki kekurangan yang ada pada siklus I yaitu dengan pembimbingan yang lebih merata dan memperkecil anggota kelompok hasil tes prestasi pada siklus II rerata 82,16 dan ketuntasan 22 siswa atau 88\%. Perbandingan hasil tes prestasi belajar pra siklus, siklus I dan siklus II setelah dilakukan ulangan pada akhir siklus diperoleh data sebagai berikut.

Tabel 2. Perbandingan Hasil Belajar Matematika Pra Siklus, Siklus I, dan Siklus II

\begin{tabular}{clccc}
\hline No & Prestasi Hasil Belajar & Prasiklus & Siklus I & Siklus II \\
1 & Nilai tertinggi & 78 & 94 & 100 \\
2 & Nilai terendah & 48 & 58 & 64 \\
3 & Nilai rata-rata & 62,88 & 74,08 & 82,16 \\
4 & Ketuntasan Belajar & $40 \%$ & $68 \%$ & $88 \%$ \\
\hline
\end{tabular}


Berdasarkan data di atas dapat disimpulkan bahwa pembelajaran dengan menggunakan media Pakar Pati dengan metode demonstrasi dan ekperimen dapat meningkatkan hasil belajar dari rerata 62,88 pada prasiklus menjadi 82,16 pada siklus II. Ketuntasan belajar pada prasiklus $40 \%$, pada siklus I meningkat menjadi $68 \%$ dan pada siklus II meningkat menjadi $88 \%$. Ini berarti, pada siklus I ada peningkatan ketuntasan belajar dari $28 \%$ pada pra siklus menjadi $68 \%$ pada siklus I, sedangkan pada siklus II meningkat dari $68 \%$ pada siklus I menjadi $88 \%$ pada siklus II. Pembelajaran dengan menggunakan menggunakan media Pakar Pati dengan metode demonstrasi dan ekperimen dapat meningkatkan ketuntasan belajar dari $40 \%$ pada prasiklus menjadi $88 \%$ pada siklus II.

Proses pembelajaran yang dilakukan guru hendaknya sesuai tujuan yang akan dicapai. Menurut Sudjana (2005) proses pembelajaran atau pengajaran adalah hubungan siswa dengan lingkungan belajar yang didesaian sedemikian rupa untuk mencapai tujuan pembelajaran, yakni kompetensi yang diharapkan dimiliki siswa sesudah menyelesaikan proses pembelajaran dan pengalaman belajarnya. Tujuan pengajaran adalah diperolehnya bentuk perubahan tingkah laku baru pada siswa, sebagai akibat dari proses belajar mengajar

Berkat intervensi penggunaan media Pakar Pati melalui metode demonstrasi dan ekperimen, kemampuan berpikir kritis dan hasil belajar ada kenaikan. Hal ini disebabkan penggunaan media Pakar Pati dengan metode demonstrasi dan ekperimen, kondisi siswa menjadi aktif mengemukakan pendapat, aktif dalam diskusi, dan aktif memperhatikan demonstrasi. Hal ini sesuai karakteristik pembelajaran menggunakan media menurut pendapat Hamzah (2001) media adalah suatu benda atau alat-alat yang dapat dilihat maupun didengar agar membuat cara berkomunikasi lebih efektif.

Menurut Nasution (2005) media adalah alat yang membantu dalam mengajar agar efektif. Pembelajaran yang berkaitan dengan akar pangkat tiga sebenarnya dapat dilaksanakan dalam pembelajaran yang konkret dan menyenangkan. Salah satu alat bantu untuk mengkongkritkan materi 
akar pangkat tiga yaitu media Pakar Pati. Pemilihan media pembelajaran yang tepat menyebabkan pembelajaran dapat berjalan dengan baik dan lebih efektif. Penggunaan media Pakar Pati membuat siswa lebih aktif dan senang dalam pembelaajran matematika materi akar pangkat tiga. Penggunaan media pembelajaran dapat memberikan stimulus, mempermudah siswa memahami konsep, dan membuat siswa cepat menyelasaikan tugas (Rosidah, 2020).

Penerapan menggunakan media Pakar Pati dengan metode demonstrasi dan ekperimen berdampak perubahan situasi kelas dan siswa. Pada siklus II proses pembelajaran menjadi lebih baik karena penggunaan menggunakan media Pakar Pati dengan metode demonstrasi dan ekperimen dan melaksanakan bimbingan dengan merata serta memperkecil jumlah anggota kelompok. Hal ini menyebabkan kemampuan berpikir kritis dan hasil belajar menjadi meningkat. Menurut Dimyati (2002) pembelajaran menjadi efektif jika dilakukan dalam kelompok kecil. Selain itu memberi kesempatan siswa untuk diskusi. Menurut Djamarah (2002) teknik diskusi merupakan teknik proses pembelajaran yang dilakukan oleh guru di sekolah. Pada saat diskusi terjadi proses belajar mengajar, dimana hubungan antara dua atau lebih individu yang terlibat, saling tukar menukar informasi pengalaman, memecahkan masalah dapat terjadi semua aktif. Menurut Syah (2006) demonstrasi merupakan metode mengajar yang dilakukan dengan cara mempertunjukkan atau memeragakan barang, kejadian, urutan melakukan kegiatan, baik secara langsung maupun melalui penggunaan barang tiruan sesuai dengan materi pelajaran yang diajarkan.

Menurut Roestiyah (2001) menyatakan bahwa metode eksperimen merupakan suatu cara mengajar di mana siswa melakukan kegiatan percobaan tentang suatu hal, mengamati prosesnya, kemudian hasil pengamatan dipresentasikan dan dinilai oleh guru. Dalam penelitian ini kelompok kecil yang digunakan tiap kelompok 4-5 anggota. Kelebihan penerapan melalui media Pakar Pati dalam pembelajaran matematika pada siklus II antara lain: membuat siswa lebih percaya diri, merangsang kreativitas 
siswa dalam bentuk ide, gagasan, prakarsa, dan terobosan baru dalam memecahkan masalah, dan meningkatkan kemampuan berpikir kritis belajar.

Pembelajaran menggunakan media pakar pati dapat meningkatkan kemampuan berpikir kritis siswa dalam pembelajaran matematika materi akar pangkat tiga. Peningkatan kemampuan berpikir kritis siswa terlihat dalam kemampuan siswa dalam merumuskan masalah, mengumpulkan data, menganalisis, menanyakan dan menjawab pertanyaan, melakukan observasi dan memberikan kesimpulan.

Hal ini sejalan dengan pendapat Lambertus (2009) berpikir kritis adalah potensi yang dimiliki oleh setiap orang, yang dapat dilatih, dapat diukur, serta dikembangkan. Selain itu, terdapat keterkaitan antara matematika dengan berpikir kritis. Menurut Kowiyah (2012) pada saat mempelajari matematika hal yang akan dipelajari adalah bagaimana merumuskan masalah, merencanakan penyelesaian, mengkaji langkah-langkah penyelesaian, membuat dugaan bila data yang disajikan kurang lengkap, sehingga diperlukan sebuah kegiatan yang disebut berpikir kritis.

Iakovos (2011) berpikir kreatif dan berpikir kritis memiliki peranan penting dalam pendidikan dan merupakan tujuan fundamental dalam pembelajaran. Ada empat bagian penting untuk mengembangkan kemampuan berpikir kritis yaitu mengklarifikasi terus-menerus; mengajukan pertanyaan yang tepat untuk mengklarifikasi, mempertimbangkan validitas sumber, memecahkan masalah dan membuat kesimpulan.

Berpikir kritis memiliki aktivitas mental tentang memecahkan masalah, menganalisis asumsi, memberi alasan, menilai, melakukan penyelidikan, serta mengambil keputusan. Proses pengambilan keputusan, kemampuan untuk menemukan, menganalisis dan menilai data sangat penting. Orang yang berpikir kritis akan mencari, menganalisis dan mengevaluasi informasi, membuat kesimpulan berdasarkan data dan fakta yang ditemukan, lalu mangambil keputusan.

Untuk mengetahui kemampuan berpikir kritis siswa dalam mengerjakan tes matematika, salah satu hal dapat dilakukan guru adalah 
mengidentifikasi kemampuan berpikir kritis siswa pada saat menyelesaikan masalah. Oleh sebab itu, guru perlu mengamati siswa pada waktu melakukan kegiatan menyelesaikan masalah. Menurut Shadiq (2009), untuk menyelesaikan suatu soal pemecahan masalah ada empat langkah yang dapat dilakukan yaitu: memahami masalahnya, merencanakan cara penyelesaian, melaksanakan rencana, dan menafsirkan hasilnya.

Penggunaan media pakar pati dapat meningkatkan kemampuan berpukir kritis juga dapat meningkatkan hasil belajar. Hasil belajar meningkat dalam kemampuan memecahkan masalah dan memahami materi akar pangkat tiga. Keunggulan menggunakan media Pakar Pati pada pembelajaran matematika materi akar pangkat tiga yaitu menjadikan siswa lebih aktif, dan antusias terhadap pembelajaran, lebih fokus memperhatikan demonstrasi, menggunakan media, diskusi, mengemukakan pendapat dan menulis, dan dapat terlibat langsung untuk melakukan praktik. Siswa lebih banyak melakukan kegiatan belajar, sebab tidak hanya mendengarkan penjelasan guru, tetapi juga berbagai latihan serta melakukan aktivitas lain seperti mengamati, mendemonstrasikan, menjawab pertanyaan melakukan, menganalisis data dan menyimpulkan.

Menurut Sutjipto (2011), media pembelajaran merupakan perangkat yang dapat membantu proses pembelajaran dan berfungsi untuk menjelaskan makna pesan yang disampaikan, sehingga dapat mencapat tujuan pembelajaran dengan lebih baik dan sempurna. Untuk membang-kitkan dan menumbuhkan kemampuan berpikir kritis, minat, motivasi dan aktifitas belajar paserta didik peran guru sangat penting. Penggunaan media pembelajaran dan pemilihan model pembelajaran yang tepat dapat membantu meningkatkan kemampuan berpikir kritis dan hasil belajar siswa. Media pembelajaran Pakar Pati terbukti dapat membantu meningkatkan kemampuan berpikir kritis dan hasil belajar matematika. Proses pembelajaran menggunakan media pembelajaran dapat membantu guru untuk memperjelas materi dan materi yang abstrak menjadi lebih kongkrit. 


\section{Penutup}

Penggunaan media Pakar Pati dalam pembelajaran matematika dapat meningkatkan kemampuan berpikir kritis dan hasil belajar matematika pada materi akar pangkat tiga. Penggunaan media Pakar Pati membuat siswa lebih aktif dan senang dalam pembelajaran matematika khususnya pada materi akar pangkat tiga. Siswa sudah mencapai nilai KKM yang telah ditetapkan sekolah. Kemampuan siswa dalam merumuskan masalah, mengumpulkan data, menganalisis, menanyakan, dan menjawab pertanyaan, melakukan observasi, dan memberikan kesimpulan menjadi lebih meningkat. Hasil belajar juga meningkat dalam kemampuan memecahkan masalah dan memahami materi akar pangkat tiga.

Sebagai saran, pemanfaatan media Pakar Pati bagi siswa kelas V pada materi akar pangkat dapat digunakan secara maksimal, karena siswa sangat antusias untuk menggunakan media ini. Guru yang akan menggunakan media Pakar Pati ini dapat membuat beberapa buah agar semua siswa lainnya juga dapat menggunakan media ini secara bersamasama dalam proses pembelajaran. Pembelajaran penggunaan media Pakar Pati dapat dikembangkan dalam pembelajaran selanjutnya. Guru dapat memodifikasi dan mengembangkan agar lebih baik dan bermanfaat dalam dunia pendidikan. Kepala sekolah diharapkan mampu mendorong guru untuk mengembangkan media pembelajaran inovatif yang relevan dengan kebutuhan pembelajaran di kelas masing-masing.

\section{Ucapan Terima Kasih}

Penulis menyampaikan penghargaan serta ucapan terima kasih yang sebesar-besarnya kepada (a) Direktorat GTK Pendidikan Dasar Kemendikbud RI yang telah menerbitkan artikel ini melakui jurnal Didaktika Pendidikan Dasa, (b) Korwil dan Pengawas Dikpora Kecamatan Banjarmangu yang telah memberikan bimbingan dan dorongan untuk melakukan inovasi dalam pembelajaran, (c) Kepala SD Negeri 1 kendaga kecamatan Banjarmangu yang telah memberikan izin dan motivasi dalam melaksanakan penelitian, 
serta (d) Bapak dan Ibu guru SD Negeri 1 kendaga yang telah membantu dalam kegiatan pembelajaran dan penelitian.

\section{Daftar Referensi}

Arikunto, S. (2012). Dasar-Dasar Evaluasi Pendidikan. Jakarta:Bumi Aksara.

Deswani. (2009). Proses Keperawatan dan Berpikir Kritis. Jakarta: Salemba Medika.

Dimyati. (2005). Belajar dan Pembelajaran. Jakarta: Depdikbud.

Djamarah. (2002). Strategi Belajar mengajar. Jakarta : Rineka Cipta

Hamalik, O. ( 2002). Proses Belajar Mengajar. Jakarta: Bumi Aksara

Hamzah. (2005). Strategi Penerapan Alat Peraga di Sekolah. Semarang: Alat Peraga Pendidikan.

Harsanto. (2005). Melatih Anak Berpikir Analitis Kritis dan Kreatif. Jakarta: Grasindo.

Iakovos, T. (2011). Critical and Creative Thinking in the English Language Classroom. International Journal of Humanities and Social Science.Vol 1 , No 8 .

Iskandar. (2009). Psikologi Pendidikan. Jakarta: Gaung Persada Pers.

Kowiyah. (2012). Kemampuan Berpikir Kritis. Jurnal Pendidikan Dasar, 3 (5): 175-179.

Lambertus. (2009). Pentingnya Melatih Keterampilan Berpikir Kritis dalam Pembelajaran Matematika di SD. Forum Kependidikan, 28(2): 136-142.

Muhsetyo. (2007). Pembelajaran Matematika di SD. Jakarta: Universitas Terbuka.

Nasution. (2005). Penerapan Alat Peraga di Sekolah. Bandung : Rosdakarya

Purwanto, N. 2008. Psikologi Pendidikan. Jakarta: Remaja Rosdakarya.

Rahmi, F. (2020). Penggunaan Media "Layar Putar" pada Pembelajaran Tematik Siswa Tuna Rungu. Jurnal Didaktika Pendidikan Dasar, 4(1), 75-92. https:// doi.org/10.26811/didaktika.v4i1.130

Rosidah, F. (2020). Teknik Showing Berbantuan Multi Media Kreatif untuk Meningkatkan Keterampilan Menulis Teks Narasi. Jurnal Didaktika Pendidikan Dasar, 4(1), 169-192. https://doi.org/10.26811/didaktika.v4i1.161 
Roestiyah, N.K. (2001). Strategi Belajar Mengajar. Jakarta: Rineka Cipta.

Shadiq, F. (2009). Pemecahan Masalah, Penalaran dan Komunikasi. Diklat Instruktur/ Pengembangan Matematika SMA Jenjang Dasar. Yogyakarta: Pusat Pengembangan Guru Matematika.

Sudjana, N. (2004). CBSA dalam Proses Belajar Mengajar. Bandung: Sinar Baru

Sutjipto, B. (2011). Media Pembelajaran Manual dan Digital. Jakarta: Ghalia Indonesia.

Syah, M. (2004). Psikologi Pendidikan dengan Pendekatan Baru. Bandung Remaja Rosda Karya. 